\title{
ART
}

\section{MUSEUM-SKANSENS OF LEMKO'S CULTURE IN THE CONTEXT OF THE APPROVAL AND CONSERVATION OF UKRAINIAN IDENTITY}

\author{
Candidate of the Art critic, docent Olga Fabryka-Protska, \\ Ukraine, Ivano-Frankivsk, \\ Precarpathian National University after Vasil Stefanyk
}

\section{DOI: https://doi.org/10.31435/rsglobal_ws/31082019/6647}

\section{ARTICLE INFO}

Received: 22 June 2019

Accepted: 22 August 2019

Published: 31 August 2019

\section{KEYWORDS}

museum-skansens, Lemkos, Ukrainians, exhibits, material and spiritual culture, identity.

\begin{abstract}
The article deals with the specificity of Scansen museums as a form of research into the cultural heritage of Lemkos. They are the centers of preservation of Ukrainian subetnos culture today. It is proved that museums retain a wealth of forms of ancient Slavic traditions and are a source of inspiration for contemporary artists of different industries. Studying and preserving monuments of Ukrainian culture as a vivid manifestation of identification is essential for the revival, preservation and consolidation of national consciousness for future generations.
\end{abstract}

Citation: Olga Fabryka-Protska. (2019) Museum-Skansens of Lemko's Culture in the Context of the Approval and Conservation of Ukrainian Identity. World Science. 8(48), Vol.3. doi: 10.31435/rsglobal_ws/31082019/6647

Copyright: (C) 2019 Olga Fabryka-Protska. This is an open-access article distributed under the terms of the Creative Commons Attribution License (CC BY). The use, distribution or reproduction in other forums is permitted, provided the original author(s) or licensor are credited and that the original publication in this journal is cited, in accordance with accepted academic practice. No use, distribution or reproduction is permitted which does not comply with these terms.

Introduction. Culture cannot exist without the past. It is based on the collective experience of the people, their traditions, knowledge, skills. Lemkos (Rusyns) is the ancient name of an ethnographic group of Slavs who lived in mountainous areas on the border of modern Ukraine, Poland and Slovakia. The life and culture of this people are unique and one of a kind.

An important part of the cultural heritage of Lemkos are archival, museum and library collections, scansen museums, which arose as a result of the activities of cultural, educational, public, scientific centers and individual enthusiasts not only in Ukraine but also in different countries of the world. Skansen is a widespread form of ethnographic museums that undergo a comprehensive reconstruction of the past, whose historical constructions are not only individual exhibits but entire complexes. People's cultural monuments belong to the main assets of the historical and cultural heritage. They retain a wealth of forms of ancient Slavic traditions and are a source of inspiration for modern architects.

The study and preservation of historical, ethnographic and artistic monuments is of great importance for the revival, preservation and promotion of the national consciousness of the Ukrainian community in the world. Appeal to the issues of scientific understanding of the spiritual and material culture of Lemkos, in particular in the field of museums is relevant today.

Research results. On the territory of Ukraine in the museums of Kiev, Uzhgorod many objects of everyday life, tools of agricultural machinery, as well as works of Lemko folk art are stored. Sets of folk clothing and household items from different counties of northern Lemkivshchyna, Transcarpathian region can be seen in the Museum of Folk Architecture and Life in Lviv.

The life of the Lemkos of the Transcarpathian region is also represented in the Museum of History and Culture of the village of Luta, as well as in the Local History Museum and the Museum of Folk Architecture and Life in Uzhgorod. Thanks to ethnographic expeditions, employees of the 
Museum of Ethnography and Arts in the Academy of Sciences of Ukraine in Lviv and employees of the Lviv Museum of History have collected a large number of Lemko monuments, including clothing, agricultural implements, folk crafts and more.

In 1972, in the territory of Western Ukraine, in particular in Lviv, the Museum of Scansen of Folk Architecture and Life was created. Its territory is $46 \mathrm{~g}$. More than 120 examples of folk architecture of the XVIII-XX centuries are on display. The exposition was built by ethnographic zones: Boykivshchyna, Transcarpathia, Hutsulshchyna, Lemkivshchyna, Bukovyna, Pokuttya, Podillya, Polesie, Volyn and the historical and administrative zone - Lviv region. The Lemkivskyi zone consists of three estates from the Transcarpathian region. In 1992, the first Lemko church (like the church of 1841) was built on the territory of the Museum. Kotan, Yaselsky County (Poland).

Every year on the territory of the Museum-scansen the regional public-social associations "Lemkivshchyna" and the Foundation of the Lemkivshchyna Association in Lviv hold various holidays, folk festivals, kermeshes, etc. [4].

A large number of Lemko families live after resettlement in Lviv, Ivano-Frankivsk, Luhansk, Zhytomyr, Kyiv and Ternopil regions.

In order to preserve the national identity of the Lemkos, to develop the unique Lemko culture and to popularize it in the city of Monastyrysk, the Lemko Museum of Culture and Life was opened in 1996 at the district branch of the Lemkivshchina Society. The initiators of the opening of the museum were the enthusiasts of the Fr. A. Duda, S. Gurey, M. Gromosyak, O. Goynyak, M. Mykytyn, M. Tikhansky and others. On August 19, 1999, the inauguration of the Museum took place.

The main areas of activity of the museum complex should be named: scientific manning of the museum complex funds - museum collection; identify and collect monuments of the tangible and spiritual heritage of Lemkos and other objects of history and culture associated with them; study and collection of archival materials. Among the exhibits of the museum you can see icons of the XIX-XX centuries., Embroidered towels, sculptures of Mikhail Chereshnevsky, weaving and carpenter machines, carving of Lemko artists: S. Kyshchak, A. Sukhorsky, A. Krasivsky, B. Koval, M. Zawiiski, J. Odrehivsky, V. Logozi, V. Maksimovich, engraving of master of graphics V. Madzelyan, reproduction of paintings by the Lemko painter Nikifora (Epiphany Drovnyak, doll collection in national clothes made by lemkin I. Omelchenko-Krynitskaya.

The tourist pearl of the Monastyrysky Krai is the museum complex "Lemkivskoye Selo", located in the tract of Bychov, Ternopil region. Today, the director of the Skansen Museum is a native-born Vera Dudar. The museum represents the culture of an ethnographic group of Ukrainian Highlanders - Lemkos, who lived in present-day Poland, Slovakia and Ukraine. Every year on the territory of the museum complex there is an international festival of Lemko culture called "Bells of Lemkivschyna" and a children's folk festival "Lemkivsky Rats". As part of the Lemko S.V.I.T project launched in 2019, a modern museum is planned to be built in the area. Activists and employees of the Museum and Museum Complex "Lemkivskoye Selo" have for many years maintained close links with the Lemkivschyna Research Foundation, the All-Ukrainian Society of Lemkivschyna, the regional organizations of "Lemkivschyna" of Lviv, Ivano-Frankivsk, Kalush and other cities, Poland, USA, Canada, World Federation of Ukrainian Lemkiv Associations.

The first center of collecting and studying the monuments of history, ethnography and book culture of the Lemkivschyna was the Lemkivschyna Museum in Sianok (Poland), created in 1930 on the initiative of cultural and public figures I. Dobryanska, F. Kokowski, E. Konstantinovich and S. Vengrinovich. Private collectors and museum staff have collected a valuable collection of materials on the history, life and art of Lemkos [4]. The museum's collection was housed in the home of a Sinoc Greco-Catholic parish. During World War II, the Lemkivschyna Museum merged with the Museum of the Society of Friends of Sianoc Land and was renamed the Museum of the City of Sianok (Poland) [1: 513].

The Museum of Folk Architecture in Sanok (Ethnographic Park), was founded in 1958, thanks to J. Tour and the first director of the institution, A. Rybytsky. It is one of the largest open air museums (Scans museums) of Poland. It presents landmarks of the Polish-Russian border covering the territory of southeastern Poland (Bieszczady, Lower Beskidy, Doly Jasyielsko-Sanotske, Pogoże Sękowski and Dinowskie, part of the foothills of Przemysl and Stzieżowski). Among the members of the Scientific Council who have made a significant contribution to the creation of the ethnographic park in Senok should be mentioned R. Reinfus, K. Pivotsky, D. Tsiolek, I. Tlochek and A. Fastnacht and others. 
The architectural sites are located in sectors, each of which is dedicated to ethnographic groups - valleys, settlers, lemkos, fights. The purpose of the Skansen Museum is to give the impression that they are in the village of one of the mentioned groups. In accordance with this intention, the natural landscape was used. Therefore, the Lemko and Boikiv sectors are located in the forested mountainous part and the valleys and shabby sectors are in the lower regions.

Today, the museum has a large archive and a specialized library. From the beginning of its existence, it has conducted publishing activities, under which the journals "Materials of the Museum of Folk Architecture in Sanok" and "Acta Scansenologica", as well as scientific and popular science publications, are published to this day. Ethnographic groups - fights and Lemkos, Poghorzans (Polish population) and valleys (Polish-Ukrainian population), who inhabited the territory of southeastern Poland, became the subject of scientific interest of the museum [5].

There are various festivals and events on the territory of the museum in Xianok, including the "Carpathian Culture Festival" and others. The Lemko Life Museum, established in 1990 in the basement of a local Greek Catholic church, is a well-known center of conservation, study and promotion of monuments of the history and material culture of Lemkos in Poland. Activists collected ancient monuments of life (clothing, tools, decorative art, documents, photos, paintings) for residents of the village - Lemkos, who had not been evicted since World War II. The local priest, Fr. Ivan Pipka [1: 428].

Among the many Lemko culture museums in Poland, a well-known site for the preservation and study of Lemko history, culture and lifestyles is the Lemko Culture Scansen Museum in Zindranova near the Duklianski Pass at the border with Slovakia. This ethnographic and historical museum of culture of the Ruthenian-Lemkos was founded in 1968 by Lemko Fyodor Goch. On the occasion of the 25th anniversary of the Duklian operation of the Second World War, F. Gotch established a small ethnographic exposition on the territory of the traditional Lemko settlement, supplementing it with military exhibits from the times of both world wars, a forge, a windmill and a small tavern, with several architectural objects. The ethnographic part consists of household items of traditional clothing, decorative arts and folk crafts, documents, paintings, photographs of famous cultural figures (G.Hanulyak, V.Hilyak, B.-I. Antonich, I. Rusenko, N. Drovnyak).

For many years, the museum in Zindranova (Poland) functioned as a private institution, initially as a hut of Lemko culture monuments in the founder's house, and later as an open-air museum. Since 1992, the Lemko folk festival "Od Rusal to Jan" has been held annually on the territory of the Museum, since 1994 the literary and art magazine "Zagoroda" has been published. In 2018, the Museum of Lemko Culture in Zindranova celebrated its 50th anniversary. About 10 thousand people come there every year. Nowadays the museum has the status of a branch of the State Subcarpathian Museum in Krosno.

Many collections of monuments are on display in the Museum Rooms of many villages in Poland. In addition to Slovaks, the Slovak Republic is populated by other national minorities. One of these is the Rusyn-Ukrainians, who live compactly in the northeastern part of the republic. Slovak National Museum - The Museum of Ukrainian-Ruthenian Culture in Svidnyk started construction of an open-air ethnographic exposition in 1975. Initially, the Museum was founded in Medzilaborce (1956), several times it was first transferred to Pryashev (1957), later to Krasny Brod (1960) [1: 513].

From the very beginning, this national institution has been trying to create a comprehensive ethnographic exposition that, based on material documentary artifacts, would provide visitors with a holistic picture of the living conditions of Rusyn-Ukrainians in past centuries.

Since 1967, one of the main tasks of the Museum has been the study of national construction and life. The author of the scientific research and the author of the conceptual project is Doctor of History Miroslav Sopoliga. The Museum of Ukrainian Culture in Svidnyk contains about fifty monuments of folk architecture from different Russian-Ukrainian localities of Eastern Slovakia, 10 thousand ethnographic objects and specimens of decorative and applied folk art and a large amount of documentation on this subject (photographs, tape recordings, manuscript collections The museum has a library with materials that reveal the life of the Ruthenians (more than 25,000 volumes). their complexes, reminiscent of traditional agricultural estates of many villages [3].

In the 1980s, the Museum of Ukrainian Culture was an integral part of the Museum of Ukrainian Culture. one of the founders of modern fine art in Slovakia is Desideria Millogo. Museum staff collect, study, exhibit and preserve monuments of material and spiritual culture of Ukrainians, as 
well as publish a "Scientific Collection", the main purpose of which is to inform readers about the material and spiritual culture of Ukrainians-Ruthenians of Slovakia.

Folklore and ethnographic activities of the Museum's staff ensure the revival and development of the language and culture of Ukrainian-Ruthenians, the preservation of handwritten materials, special literature, archives, the publication of scientific literature in Ukrainian, etc. The Scientific Library of the Museum has over 30 thousand copies of books and scientific publications.

Since 2002, the museum has become an integral part of the Slovak National Museum. Together with other museums of ethnic minorities, it represents the national cultural policy of the Slovak Republic. During its existence, the museum has won an honorable place among museums in Eastern Slovakia and abroad. The staff of this institution maintains friendly relations with many museums, research institutes, schools in Slovakia and abroad [2]. Today, the Svidnik Museum performs multifaceted activities, the specificity of which is the dialectical combination of its three main functions: research, collectors and cultural and educational.

Museums of Lemko culture are well known far beyond Europe. In particular, in 1986, the Lemko Association of Canada established the Lemko Heritage Museum. Julian Tarnowitz-Beskid. At that time, the main organizer of the Museum was M. Masley, chairman of the Lemko Association of Canada, who is the curator of the Museum to this day. Among the exhibits are paintings by Lemko artists, carvings, Lemko clothes and household implements.

Today, a large number of exhibits have passed and today the lemmas of the southern slopes of the Carpathian Mountains are stored in the Russian Krestura and Novi Sad (Serbia and Montenegro). Numerous exhibits are found in various museums and private collections in the US and Canada.

Conclusions. Thus, museums are institutes of spiritual and social memory, where historical, artistic values are preserved, where the sacred and the eternal exist. Notwithstanding the difficult pages of history, the Lemko-Ukrainians scattered throughout the world are holy in preserving and multiplying their culture in various forms of expression, including the creation and operation of museum rooms and museum scans. Museums of Lemko culture are a treasure trove of historical and cultural heritage, and museum exhibits are carriers of invaluable information about the history and culture of the region.

\section{REFERENCES}

1. Encyclopedia of the history and culture of the Carpathian Ruthenians [Text] / Contributed by: Pavel Robert Magochiy, Ivan Pop; ag. Ed. Paul Robert Magochi; trans. From English the languages of Hope Kushko; ed. ukr. publications by Valery Padiak; maps of Paul Robert Magochi; Imp. Ed. Larisa Ilchenko. Uzhhorod: V. Padiak's edition, 2010. 680

2. Krasovsky I., Chelak I. Encyclopedic Dictionary of Lemkivshchyna. Lviv, Astrolabia, 2013. 751

3. Sopoliga M. Ukrainians in the Carpathian border regions: problems of acculturation, assimilation, identification. Proceedings of the Swidnik International Scientific Conference, June 17-18, 2011. Scientific Collection of the Museum of Ukrainian Culture in Swidnik. Witness, 2011. 350-360.

4. Fabryka-Protska O. Museums of Lemko culture as centers of preservation of spiritual and material culture of Ukrainian subetnos. Collection of papers and abstracts of the VIII International Scientific and Practical Conference "Traditions and contemporary status of the state of culture and arts of culture and arts" (Minsk, Belarus, September 7-8, 2017). / gal. ed. A. I. Lakotka; Center for the Study of Belarusian Culture, Language and Literature of the National Academy of Sciences of Belarus. - Minsk: Law and Economy, 2018. P.777-779.

5. Zatorska M. Muzeum Budownictwa Ludowego w Sanoku https://skanseny.net/skansen/sanok. 